\title{
Functional Remodeling of Gap Junction-Mediated Electrical Communication between Adrenal Chromaffin Cells in Stressed Rats
}

\author{
Claude Colomer, ${ }^{1,2,3,4}$ Luis A. Olivos Ore, ${ }^{1,2,3,4,5}$ Nathalie Coutry, ${ }^{1,2,3,4}$ Marie-Noëlle Mathieu, ${ }^{1,2,3,4}$ Sébastien Arthaud, ${ }^{6}$ \\ Pierre Fontanaud, ${ }^{1,2,3,4}$ Irena Iankova, ${ }^{7}$ Françoise Macari, ${ }^{1,2,3,4}$ Erwan Thouënnon, ${ }^{6}$ Laurent Yon, ${ }^{6}$ Youssef Anouar, ${ }^{6}$ and \\ Nathalie C. Guérineau ${ }^{1,2,3,4}$ \\ ${ }^{1}$ Institute of Functional Genomics, ${ }^{2}$ Centre National de la Recherche Scientifique UMR5203, ${ }^{3}$ Inserm U661, and ${ }^{4}$ University of Montpellier (IFR3), 34094 \\ Montpellier, France, ${ }^{5}$ Department of Toxicology and Pharmacology, Complutense University of Madrid, 28040 Madrid, Spain, ${ }^{6}$ Inserm U413, University of \\ Rouen, 76821 Mont-Saint-Aignan, France, and 'Inserm U896, 34298 Montpellier, France
}

An increase in circulating catecholamine levels represents one of the mechanisms whereby organisms cope with stress. In the periphery, catecholamines mainly originate from the sympathoadrenal system. As we reported, in addition to the central control through cholinergic innervation, a local gap junction-delineated route between adrenal chromaffin cells contributes to catecholamine exocytosis. Here, we investigated whether this intercellular communication is modified when the hormonal demand is increased as observed during cold stress. Our results show that in cold exposed rats, gap-junctional communication undergoes a functional plasticity, as evidenced by an increased number of dye-coupled cells. Of a physiological interest is that this upregulation of gap-junctional coupling results in the appearance of a robust electrical coupling between chromaffin cells that allows the transmission of action potentials between coupled cells. This enhancement of gap-junctional communication parallels an increase in expression levels of connexin36 (Cx36) and connexin43 (Cx43) proteins. Both transcriptional and posttranslational mechanisms are involved because $\mathrm{Cx} 36$ transcripts are increased in stressed rats and the expression of the scaffolding protein zonula occludens-1, known to interact with both $\mathrm{Cx} 36$ and $\mathrm{Cx} 43$, is also upregulated. Consistent with an upregulated coupling extent in stressed rats, the cytosolic $\mathrm{Ca}^{2+}$ concentration rises triggered in a single cell by an iontophoretic application of nicotine occur simultaneously in several neighboring cells. These results describe for the first time a functional plasticity of junctional coupling between adult chromaffin cells that should be crucial for adaptation to stress or sensitization to subsequent stressors.

Key words: gap-junctional communication; connexins; nicotinic stimulation; cold exposure; dual patch clamp; rat acute adrenal slices

\section{Introduction}

Stimuli that act as stressors elicit complex responses that enable an organism to cope with a changing environment and to respond effectively to a threat for its survival. Adaptative responses to stress are mediated by a synergistic activation of a neuronal and neuroendocrine axis (i.e., the hypothalamo-pituitary-adrenocortical axis, the adrenomedullary hormonal system, and the sympathetic noradrenergic system) (Herman and Cullinan,

\footnotetext{
Received Dec. 18, 2007; revised April 18, 2008; accepted May 15, 2008.

This work was supported by grants from Centre National de la Recherche Scientifique, Institut National de la Santé et de la Recherche Médicale, Ministère de l'Enseignement Supérieur et de la Recherche, Fondation pour la Recherche Médicale, Association pour la Recherche sur le Cancer Régionale, Région Languedoc-Roussillon, and Conseil Régional de Haute Normandie. We thank Drs. M. G. Desarménien, P. F. Méry, V. Homburger, A. Varrault, and P. Mollard for helpful discussions in preparing this manuscript and D. Haddou, A. Carrette, and P. Didier for technical assistance. We also thank N. Lautredou at the microscope facility of Montpellier RIO Imaging-Centre Régional d'Imagerie Cellulaire plateform.

The authors declare no competing financial interests.

Correspondence should be addressed to Dr. Nathalie C. Guérineau, Department of Endocrinology, Institute of Functional Genomics, 141 rue de la Cardonille, 34094 Montpellier CEDEX 05, France. E-mail: nathalie.guerineau@igf.cnrs.fr.

D01:10.1523/JNEUROSC1.5597-07.2008

Copyright $\odot 2008$ Society for Neuroscience $\quad$ 0270-6474/08/286616-11\$15.00/0
}

1997; Charmandari et al., 2005), but the relative intensity of their respective stimulation is stressor specific (Goldstein and Kopin, 2007). Catecholamines are one of the primary mediators for many of the physiological consequences of the response to stressors by the organism. In the adrenal medulla, the main peripheral tissue involved in catecholamine release, stress induces synthesis and release of catecholamines (Kvetnansky and Sabban, 1993), consistent with an increase in the activity of catecholamine biosynthetic enzymes (Sabban and Kvetnansky, 2001). Because an increase in catecholamine secretion is a key initial event in response to stressors, it is of interest to investigate how chromaffin cells behave to ensure increased catecholamine release in the blood circulation. In vivo, the secretion of catecholamines by chromaffin cells is chiefly controlled by the synaptic release of acetylcholine from splanchnic nerve terminals synapsing onto chromaffin cells (Douglas, 1968; Wakade, 1981). However, as reported by our group (Martin et al., 2001), in addition to this synaptic pathway, gap junction-mediated intercellular communication between chromaffin cells also contributes to catecholamine secretion, and we proposed that junctional coupling may represent an efficient complement to synaptic neurotransmission 
to amplify catecholamine release. To date, whether the gap junction-delineated route can be modulated in response to stress remains unknown. Compelling evidence suggests that gap junctions might have a role in stress-induced rise in catecholamine secretion. First, gap junctions provide a widespread mechanism of intercellular dialogue by intercellular exchange of ions and metabolites, and they can therefore signal the state of activity of neighboring cells, thus allowing a coordinated multicellular response of the coupled cell clusters. Second, gap junctiondependent cell-cell cross talk is a significant player of a variety of functions such as hormone secretion from endocrine/neuroendocrine tissues (Meda, 1996; Munari-Silem and Rousset, 1996; Hatton, 1997; Caton et al., 2002; Michon et al., 2005) including the adrenal medulla in which connexin36 (Cx36) and/or connexin43 (Cx43) have been reported to functionally connect chromaffin cells in situ (Martin et al., 2001). Third, in adrenal slices, gap-junctional coupling efficiency between chromaffin cells is modulated by the sympatho-adrenal synaptic transmission (Martin et al., 2003).

These considerations prompted us to seek whether a stressful situation might modify the gap-junctional communication between rat adrenal chromaffin cells. Our data indicate that, in response to a cold exposure for $5 \mathrm{~d}$, gap-junctional coupling is dramatically enhanced. We show the appearance of a robust electrical coupling between chromaffin cells resulting in a functional propagation of cell excitation. In parallel, Cx36 and Cx43 expression is upregulated. We propose that these changes of cell-cell coupling may contribute to improvement of the stimulationsecretion coupling efficiency in the adrenal medulla, accounting for an increase in catecholamine secretion.

\section{Materials and Methods}

All procedures in this study conformed to the animal welfare guidelines of the European Community and were approved by the French Ministry of Agriculture (authorization number 34.247).

Cold stress paradigm. Male Wistar rats (Janvier) were kept in plastic cages with bedding and were continuously exposed to an ambient temperature of $4^{\circ} \mathrm{C}$ for $5 \mathrm{~d}$. Control rats were housed in similar conditions, but at $22^{\circ} \mathrm{C}$. The rooms were maintained on a $12 \mathrm{~h}$ light/dark cycle (light on from 8 A.M. to 8 P.M.). Food and water were available ad libitum. The reversibility of cold stress-induced changes was assessed in rats housed in standard conditions for $5 \mathrm{~d}$ after stress cessation. The mean body weight of animals was similar at the beginning of treatment (control: $335 \pm 22 \mathrm{~g}$, $n=9$; cold stress: $321 \pm 14 \mathrm{~g}, n=22 ; p>0.01$ ), whereas control animals gained weight $(11.8 \pm 2.2 \%)$ in contrast to stressed rats $(-4.3 \pm 4.6 \%)$ over the $5 \mathrm{~d}$ period $(p<0.01)$. Before testing, adrenals from control and stressed rats were also weighed and circulating, and adrenal catecholamine levels were titrated.

Circulating and adrenal catecholamine assays. Rat decapitation was properly conducted by skilled staff, ensuring rapid death and sample collection. Catecholamine assays were conducted as reported previously (Grouzmann et al., 1994). Briefly, adrenal glands were sonicated in $0.1 \mathrm{M}$ perchloric acid. The homogenate was centrifuged $\left(10 \mathrm{~min}, 4^{\circ} \mathrm{C}, 3000 \times\right.$ $g$ ), and the supernatant was collected and frozen until quantification. The pellets were used for measurement of protein concentrations by the Bradford method (Bradford, 1976). Aliquots of adrenal extract supernatants were injected into the HPLC system and quantified by electrochemical detection (Alexys 100 LC-EC System equipped with the Decade II detector; Antec Leyden). Results were expressed in nanomoles norepinephrine or epinephrine per milligram of protein. Trunk blood samples were collected in EDTA-precoated tubes and centrifuged. Then, plasmas were frozen at $-80^{\circ} \mathrm{C}$ until determination of circulating catecholamines. Norepinephrine and epinephrine were extracted on alumina and, as for adrenal extracts, measured by HPLC with electrochemical detection.

Adrenal slice preparation. Acute slices were prepared from rats as reported previously (Martin et al., 2001). After removal, the glands were
Table 1. Primer sequences used for $\mathrm{qPCR}$

\begin{tabular}{lll}
\hline & Forward sequence $\left(5^{\prime}-3^{\prime}\right)$ & Reverse sequence $\left(5^{\prime}-3^{\prime}\right)$ \\
\hline$r C \times 36$ & AGACCACCGGGTAGAGTGACAA & GCAGGAAGGGCCACGAA \\
$r C \times 43$ & CCCGACGACAACCAGAATG & TGGCTAATGGCTGGAGTTCAT \\
$r G u s$ & CACCACTGAGAGTAACAGGAAACAA & TCGTTGGAATCCTCCAGTATCT \\
$r$ Hprt & TGACTATAATGAGCACTTCAGGGATT & TCGCTGATGACACAAACATGATT \\
$r$ GAPDH & ATGATTCTACCCACGGCAAG & CTGGAAGATGGTGATGGTT \\
\hline$r$, Rat. & &
\end{tabular}

Table 2. Effect of exposure to cold on plasma and adrenal epinephrine and norepinephrine levels

\begin{tabular}{lcc}
\hline & Control rats $(n=7)$ & Stressed rats $(n=7)$ \\
\hline Plasma levels (nM) & & \\
$\quad$ Epinephrine & $43.6 \pm 3.2$ & $62.8 \pm 2.3^{*}$ \\
$\quad$ Norepinephrine & $364.4 \pm 12.5$ & $495.2 \pm 15.8^{*}$ \\
Adrenal levels (nmol/mg protein) & & \\
$\quad$ Epinephrine & $27.8 \pm 1.0$ & $20.5 \pm 1.1^{*}$ \\
$\quad$ Norepinephrine & $4.8 \pm 0.2$ & $2.9 \pm 0.2^{*}$ \\
\hline
\end{tabular}

${ }^{*} p<0.01$ compared with control rats.

kept in ice-cold saline for $2 \mathrm{~min}$. A gland was next glued onto an agarose cube and transferred to the stage of a Vibratome (DTK-1000 D.S.K.; Dosaka). Slices of $250 \mu \mathrm{m}$ thickness were then cut with a razor blade and transferred to a storage chamber maintained at $37^{\circ} \mathrm{C}$, containing Ringer's saline (in mm: $125 \mathrm{NaCl}, 2.5 \mathrm{KCl}, 2 \mathrm{CaCl}_{2}, 1 \mathrm{MgCl}_{2}, 1.25 \mathrm{NaH}_{2} \mathrm{PO}_{4}, 26$ $\mathrm{NaHCO}_{3}$, and 12 glucose, buffered to $\mathrm{pH}$ 7.4). The saline was continuously bubbled with carbogen $\left(95 \% \mathrm{O}_{2} / 5 \% \mathrm{CO}_{2}\right)$.

Electrophysiology. All experiments were performed in the whole-cell configuration of the patch-clamp technique (Hamill et al., 1981). Patch pipettes were pulled to a resistance of 5-8 $\mathrm{M} \Omega$ from borosilicate glass and filled with the following internal solution (in $\mathrm{mM}$ ): 140 potassiumgluconate, $2 \mathrm{MgCl}_{2}, 1.1$ EGTA, and 5 HEPES, which was titrated to $\mathrm{pH}$ 7.2 with $\mathrm{KOH}$. Adrenal slices were transferred to a recording chamber attached to the stage of an upright microscope (Axioskop FS; Zeiss) and continuously superfused with Ringer's saline at $34^{\circ} \mathrm{C}$. Membrane potentials of chromaffin cell pairs were recorded under current-clamp conditions using an EPC-9 dual patch-clamp amplifier (HEKA) and filtered at $3 \mathrm{kHz}$. The junctional current $I_{\mathrm{j}}$ was monitored under dual voltageclamp conditions (Neyton and Trautmann, 1985). To calculate the macroscopic junctional conductance $G_{\mathrm{j}}$, the $I-V$ curve in which $I_{\mathrm{j}}$ amplitude was plotted as a function of the transjunctional voltage $V_{\mathrm{j}}$ was fitted by a computed linear regression $y=a x+b$ (where $y$ corresponds to $I_{\mathrm{j}}$ and $x$ corresponds to $V_{\mathrm{j}}$ ). $G_{\mathrm{j}}$ was then given by the slope of the linear regression. Coupling ratios were calculated as the current amplitude in the nearby cell divided by the current amplitude in the stepped cell. Signals were analyzed with PulseFit 8.50 (HEKA).

Dye transfer assay. The fluorescent dye LY (Lucifer yellow-CH, lithium salt, $0.5 \mathrm{~mm}$ ) was introduced into chromaffin cells using patch pipettes. Dye transfer between gap junction-coupled cells was visualized with confocal microscopy using the $488 \mathrm{~nm}$-centered wavelength of the laser beam. The extent of LY diffusion was estimated by counting the number of neighboring cells that received dye in $15 \mathrm{~min}$. The probability of LY diffusion was expressed as a ratio corresponding to the number of injected cells that show dye transfer to adjacent cells over the total number of injected cells.

Confocal imaging of cytosolic calcium. $\mathrm{Ca}^{2+}$ changes were routinely monitored with a real-time (30-480 frames/s) confocal laser-scanning microscope equipped with an argon-krypton laser (Odyssey XL with InterVision 1.5.1 software; Noran Instruments). Cells were viewed with a $63 \times, 0.9$ numerical aperture achroplan water-immersion objective (Zeiss). The largest detection slit $(100 \mu \mathrm{m})$ of the confocal microscope was used for $\left[\mathrm{Ca}^{2+}\right]_{\mathrm{i}}$ measurements, giving bright images with a $3.1 \mu \mathrm{m}$ axial resolution. Slices were loaded with the $\mathrm{Ca}^{2+}$-sensitive fluorescent probe Oregon Green 488 BAPTA- 1 by exposure to $0.5 \mu \mathrm{M}$ Oregon Green 488 BAPTA-1 acetoxymethyl ester and Pluronic Acid F127 (Invitrogen) for $40 \mathrm{~min}$ at $37^{\circ} \mathrm{C}$. Oregon Green 488 BAPTA-1 was excited through a 
A

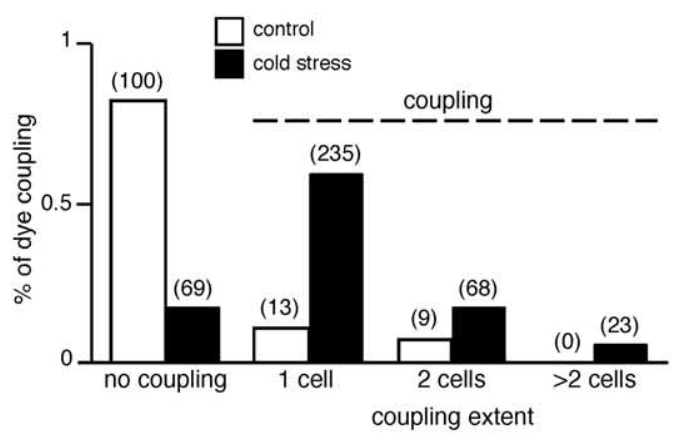

$\mathrm{Bb}$

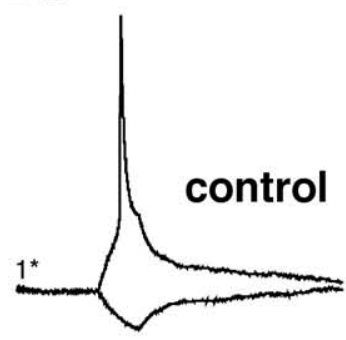

2

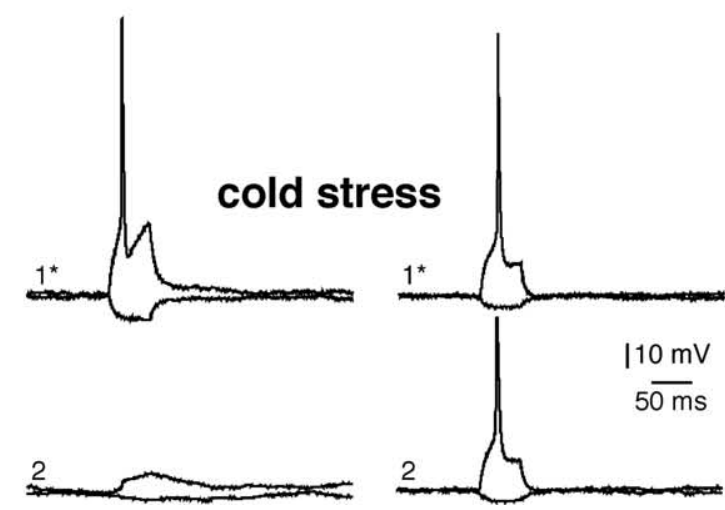

$\mathrm{Ba}$
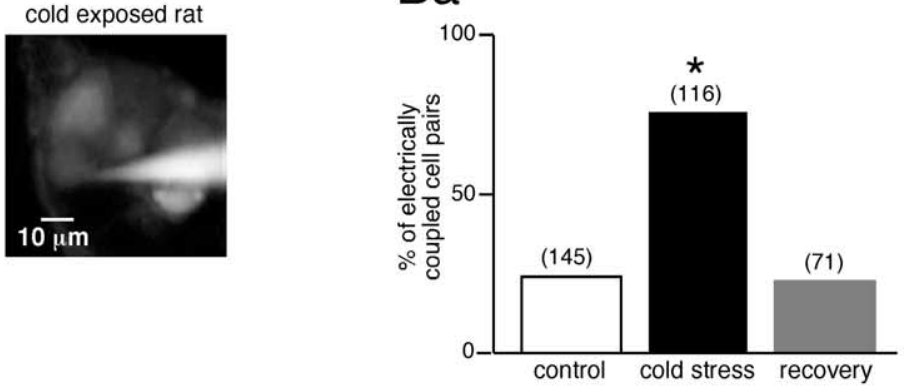

$\mathrm{Bc}$

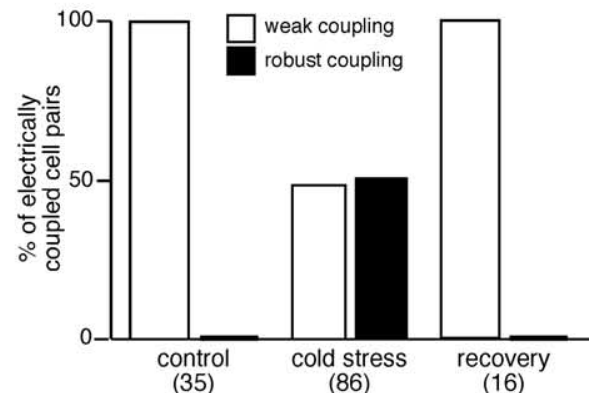

Figure 1. Upregulation of metabolic and electrical coupling between chromaffin cells in cold stressed rats. $A$, The fluorescent dye was introduced into a single chromaffin cell by passive diffusion through a patch-clamp pipette. In stressed rats, the extent of $L Y$ spreading was significantly increased. The inset exemplifies an $L Y$ diffusion to at least four neighboring cells in a cold exposed rat. The number of recorded cells is indicated in parentheses. Ba, Stress-induced reversible upregulation of electrical coupling $\left({ }^{*} p<0.01\right.$, compared with control rats). Membrane potential was monitored in chromaffin cell pairs using the dual patch-clamp technique. The number of recorded cell pairs is indicated in parentheses. $\boldsymbol{B} \boldsymbol{b}$, Appearance of a robust coupling in stressed rats. Cells were current clamped at $-60 \mathrm{mV}$, and hyperpolarizing/depolarizing steps ( $50 \mathrm{~ms}$ duration) were evoked in cell 1 (1*). The resulting voltage changes in the unstepped cell (cell 2) consisted either in small membrane hyperpolarization/depolarization (found in both control and stressed rats) or in transmission of the action potential (found only in stressed rats). BC, Histogram illustrating that the robust coupling is present in $\sim 50 \%$ of coupled chromaffin cell pairs in stressed rats. The number of recorded cell pairs is indicated in parentheses.

$488 \mathrm{~nm}$ bandpass filter, and the emitted fluorescence was collected through a $515 \mathrm{~nm}$ barrier filter. To follow the time course of Oregon Green 488 BAPTA-1 emission changes, the bright-over-time tool of the software package was applied to live images ( 120 images/s averaging four frames). Because Oregon Green 488 BAPTA-1 is a single-wavelength dye, its emission is a function of both intracellular $\mathrm{Ca}^{2+}$ and dye concentrations. $\left[\mathrm{Ca}^{2+}\right]_{\mathrm{i}}$ changes were expressed as the $F / F_{\min }$ ratio, where $F_{\min }$ was the minimum fluorescence intensity measured during the recording. Acquired data and images were then processed for analysis with Image 1.37 and Igor Pro 5.04 (Wavemetrics) software.

Iontophoretic application of nicotine. To mimic the in vivo release of transmitters into the synaptic cleft, the cholinergic secretagogue nicotine (nicotine chloride, $200 \mathrm{~mm}$ ) was iontophoretically applied onto a single chromaffin cell via a sharp microelectrode, leading to focal stimulation of a single cell (Martin et al., 2001). The concentration reported is that in the microelectrode. Nicotine was prepared from a stock solution in an acetate buffer ( $\mathrm{pH} 4$ ). At this $\mathrm{pH}$ value, nicotine was negatively charged and, consequently, could be delivered from the microelectrode by application of outward current pulses ( $50 \mathrm{nA}$ intensity, $10 \mathrm{~ms}$ duration).

Immunostaining. To process for connexin immunolabeling, adrenal glands were rapidly removed and frozen by immersion in liquid nitrogen. The glands were next mounted in Tissue-Tek O.C.T. compound and cut into 10 - to $20-\mu \mathrm{m}$-thick sections using a cryostat. Gland sections were mounted on coverslips, postfixed at $-20^{\circ} \mathrm{C}$ for $10 \mathrm{~min}$ in acetone, and incubated overnight with the following primary polyclonal antibodies: a rabbit anti-Cx36 or a rabbit anti-Cx43 (1:250; Zymed Laboratories). Sections were then incubated $1 \mathrm{~h}$ at room temperature with appropriate secondary antibodies conjugated to Alexa Fluor 488 (1:2000; Invitrogen) or Cy3 (1:2000; Jackson ImmunoResearch). Primary and secondary antibodies were diluted in PBS containing 2\% BSA and 0.1\% Triton X-100.
Stained sections were imaged with a Bio-Rad MRC-1024 confocal laserscanning microscope equipped with a krypton-argon-mixed gas laser. The specificity of the commercial antibodies has been assessed by absorption tests. Negative controls were performed by omitting primary antibodies.

Western blotting. After decapsulation, medullary tissue was separated from the cortex. To remove remaining cortical cells, samples were incubated for $10 \mathrm{~min}$ at $0-4^{\circ} \mathrm{C}$ in Ringer's saline containing $1 \mathrm{mg} / \mathrm{ml}$ collagenase type I. Membrane proteins were then isolated using lysis buffer (10 mm Tris-HCl, pH 7.4, 5 mm EDTA, 1 mm sodium orthovanadate, and $10 \mathrm{~mm} \mathrm{NaF}$ as phosphatase inhibitors, $10 \mathrm{~mm} \beta$-glycerophosphate, and $1 \%$ Triton X-100), supplemented with Mini complete protease inhibitors (Roche Applied Science). Proteins were centrifuged once for $5 \mathrm{~min}$ at $5000 \mathrm{rpm}$, and supernatants were collected. Proteins were centrifuged for $30 \mathrm{~min}$ at 13,200 rpm, and concentrations were determined using the Dc Protein Assay kit (Bio-Rad). Protein samples $(15 \mu \mathrm{g})$ were heated for 5 min at $95^{\circ} \mathrm{C}$ and separated on a $10 \%$ polyacrylamide gel [ $7 \%$ for zonula occludens-1 (ZO-1) detection] in parallel with molecular weight markers. Electrophoresed proteins were transferred onto a nitrocellulose membrane $[80 \mathrm{~V}, 60 \mathrm{~min}$ and $80 \mathrm{~V}, 75$ min using a semi-dry blotting system (Bio-Rad) for connexin and ZO-1 detection, respectively]. Blots were then blocked with $10 \%$ blocking reagent (BM Chemoluminescence Blotting Substrate kit; Roche Applied Science) in TBS (pH 7.4, 0.1\% Tween 20) for $1 \mathrm{~h}$ at room temperature with gentle agitation. Blots were then incubated with the same polyclonal antibodies raised against $\mathrm{Cx} 36$ or $\mathrm{Cx} 43$ as those used for immunofluorescence, or a polyclonal rabbit anti-ZO-1 (1:250; Zymed Laboratories) in TBS-Tween 0.1\% containing $10 \%$ blocking reagent at $4^{\circ} \mathrm{C}$ overnight. After washout, blots were incubated with secondary antibody peroxidase conjugated for $1 \mathrm{~h}$ at room temperature. This was followed by a 1 min incubation in BM Chemolu- 


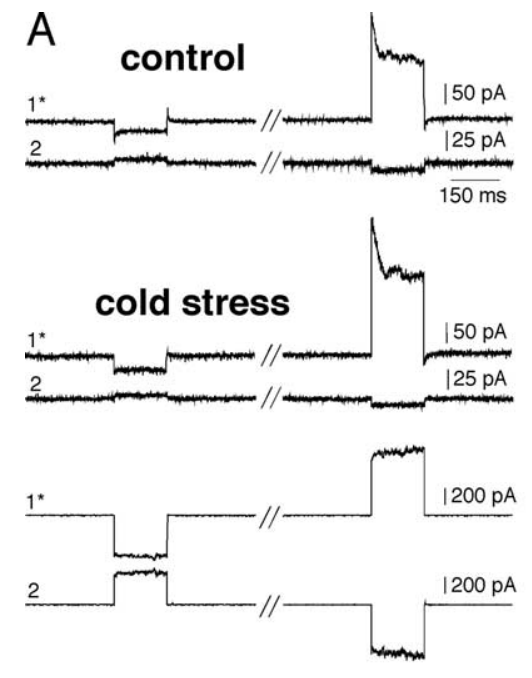

B
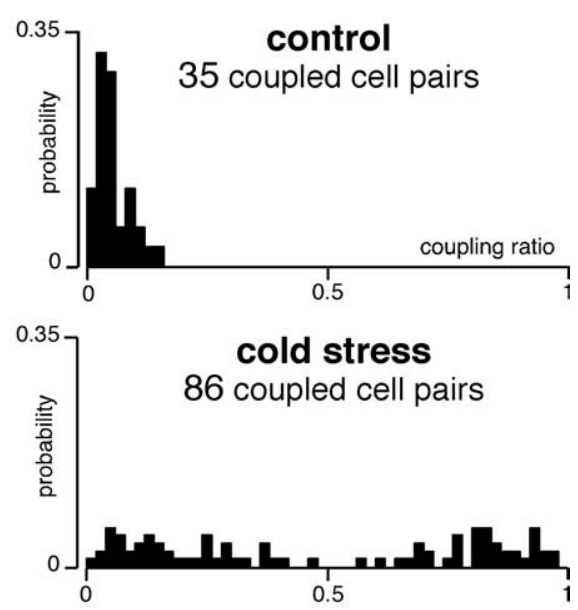

C Gj (nS)

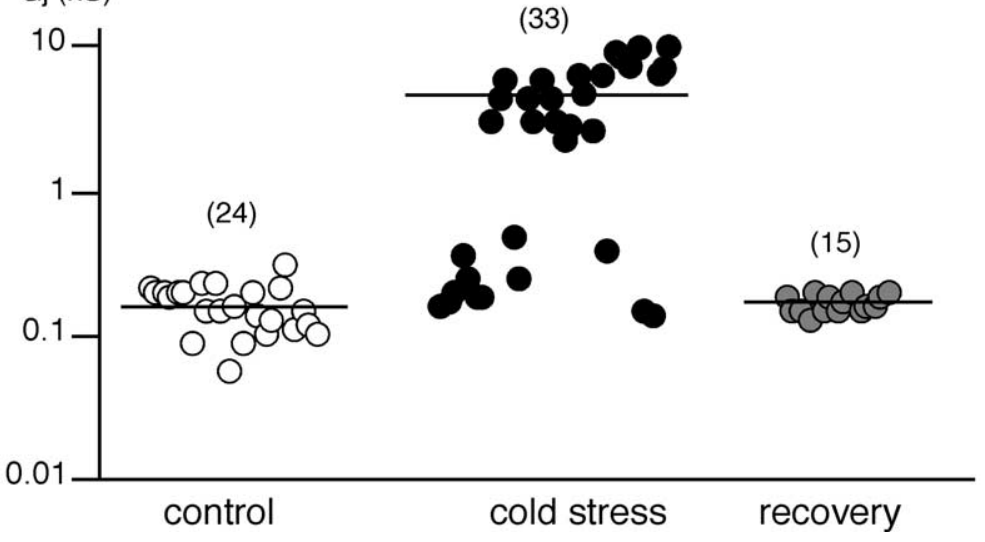

Figure 2. Junctional currents recorded in chromaffin cell pairs from control and cold stressed rats. $\boldsymbol{A}$, Representative chart recordings of junctional currents $I_{\mathrm{j}}$ in one control and two stressed (a weakly coupled and an highly coupled) cell pairs voltage clamped at $-60 \mathrm{mV}$ (hyperpolarizing voltage step at $-120 \mathrm{mV}$ and depolarizing step at $+40 \mathrm{mV}, 150 \mathrm{~ms}$ duration). The asterisk marks the stimulated cell. $\boldsymbol{B}$, Histograms illustrating the distribution range of the coupling ratio (from 0 for noncoupled pairs to 1 for highly coupled pairs) calculated from voltage-clamp measurements of $I_{j}$ (holding potential, $-60 \mathrm{mV}$; transjunctional potential from -120 to $+60 \mathrm{mV} ; 150 \mathrm{~ms}$ duration). C, Pooled data of the macroscopic junctional conductance $G_{j}$ showing the presence of two chromaffin cell populations exhibiting either low $G_{j}$ (mean, $\sim 200 \mathrm{pS}$ ) or high $G_{\mathrm{j}}$ (mean, $\sim 5 \mathrm{nS}$ ). Note that the latter is present only in stressed rats. The number of recorded cell pairs for each condition is indicated in parentheses.

minescence Blotting substrate. Labeled blots were then exposed to Fujifilm Medical X-Ray Film to visualize antibody binding. To ensure equal loading of protein samples, blots were stripped of their connexins or ZO-1 antibodies and reprobed with an actin-specific monoclonal antibody (actin, pan Ab-5, clone ACTN05, 1:1000; Interchim). Intensities of $\mathrm{Cx} 36, \mathrm{Cx} 43$, and ZO-1 bands were normalized to those of actin and quantified using ImageJ software.

Quantification of $m R N A$ expression levels by real-time PCR. Total RNA was extracted from macrodissected adrenal medulla (same protocol as used for Western blot experiments) and treated with DNase I using the RNeasy Micro extraction kit (Qiagen). RNA $(1 \mu \mathrm{g})$ was first reverse transcribed using Superscript III reverse transcriptase (Invitrogen) and $250 \mathrm{ng}$ of random hexamer (Amersham Biosciences) in a final volume of $20 \mu$ l. Real-time PCR analyses of $C x 36, C x 43$, and housekeeping genes were performed using SYBR Green PCR master mix (Applied Biosystems) with 1:10 of the reverse transcription reaction and were performed on an ABI 7500 Sequence Detector (Applied Biosystems). Primer sequences for $C x 36, C x 43$, and housekeeping genes are given in Table 1. The concentration of the primers used was $300 \mathrm{~nm}$ each for $C \times 43$ and housekeeping genes and $900 \mathrm{~nm}$ for $C x 36$. After an initial denaturation step for $10 \mathrm{~min}$ at $95^{\circ} \mathrm{C}$, the thermal cycling conditions were 40 cycles at $95^{\circ} \mathrm{C}$ for $15 \mathrm{~s}$ and $60^{\circ} \mathrm{C}$ for $1 \mathrm{~min}$. Each sample value was determined from triplicate measurements. The selection of appropriate housekeeping genes was performed with geNorm (Vandesompele et al., 2002). Expression of Cx36 and Cx43 transcripts was normalized to the geometric mean of the expression levels of three housekeeping genes [Hprt (hypoxanthine-guanine phosphoribosyltransferase), GAPDH (glyceraldehyde-3-phosphate dehydrogenase), and Gus (glucuronidase)], according to the formula $\mathrm{Cx} /$ geometric mean (R1, R2, R3) = $2-{ }^{(C t}[\mathrm{Cx}]$-arithmetic mean $\left.[C t(\mathrm{R} 1), C t(\mathrm{R} 2), C t(\mathrm{R} 3)]\right)$, where $C t$ is the threshold cycle and R1, R2, and $\mathrm{R} 3$ are the three reference genes.

Solutions and chemicals. Nicotine, LY, collagenase type I, lectin from Triticum vulgaris, and the gap junction blocker carbenoxolone were purchased from Sigma. Primers for quantitative PCR (qPCR) were purchased from MWG-Biotech.

Statistics. Numerical data are expressed as the mean \pm SEM. Differences between groups were assessed by using the nonparametric MannWhitney $U$ test. An unpaired Student's $t$ test was used to compare means. Percentages were compared using a contingency table and the $\chi^{2}$ test. Differences with $p<0.01$ were considered significant.

\section{Results}

As a validation of the cold stress paradigm, we measured adrenal weight and catecholamine content (intra-adrenal and in the blood circulation), and we found that these parameters were altered by the cold exposure. As reported by Kvetnansky et al. (1971), the adrenal weight was significantly increased (mean weight of the two adrenals for each rat: stressed rats, $68.7 \pm$ $3.2 \mathrm{mg}, n=9$ vs untressed rats, $57.2 \pm 1.6$ $\mathrm{mg}, n=9$; $p<0.01)$. Consistent with enhanced synthesis and release of catecholamines commonly observed in response to a stressful situation (Kvetnansky et al., 1998), plasma levels of epinephrine and norepinephrine were also increased (by 44 and 36\%, respectively; $p<0.01$ ) (Table 2). Concomitantly, the adrenal content of the two catecholamines was reduced by $25 \%$ for epinephrine and by $38 \%$ for norepinephrine $(p<0.01)$ (Table 2).

\section{Appearance of gap junction-mediated robust electrical coupling between chromaffin cells in cold stressed rats} The effects of a $5 \mathrm{~d}$ cold exposure on gap junction-mediated cell-cell communication was investigated by imaging the diffusion of LY from a single patch-clamped chromaffin cell to neighbors. Both the percentage $(82.2 \%, n=382$ vs $18.0 \%, n=122$ in controls) and the spreading extent of dye coupling between chromaffin cells (Fig. 1A) were significantly upregulated in cold stressed rats. Although the spreading did not usually exceed one to two cells in controls, it could be extended to more than two to four cells in stressed animals (Fig. $1 A$, inset). To determine the functional relevance of this increased gap-junctional communication, the membrane potential of chromaffin cell pairs was monitored in the whole-cell configuration of the dual patchclamp technique (Fig. $1 B$ ). Consistent with LY data, a significant 
electrical coupling evidenced by voltage changes reflected in the unstepped cell was recorded in $79.3 \%$ of cell pairs in stressed rats $(n=116)$ versus $24.1 \%$ in controls $(n=145 ; p<0.01)$ (Fig. $1 \mathrm{Ba}$ ). It is noteworthy that this increase in electrical coupling was fully reversible. Five days after cold stress cessation, the electrical coupling between chromaffin cells did not differ from the control condition $(22.5 \%, n=71$ pairs vs $24.1 \%, n=145$ pairs in control; $p>0.01$ ) (Fig. $1 \mathrm{Ba}$ ). Among cell pairs, the voltage changes in response to hyperpolarizing/depolarizing current injected into the stimulated cell were reflected as variably attenuated responses in the unstepped cell (Fig. $1 B b, B c$ ). In all coupled cell pairs from control rats $(n=35)$, the action potential was distorted and led to a small depolarization in the coupled cell, thus indicating a weak coupling. However, in cold stressed rats, only one-half of coupled pairs exhibited a weak coupling. In the remaining half, a robust coupling led to the transmission of suprathreshold responses resulting in action potentials. Together, these data strongly suggest the presence of two chromaffin cell populations, a weakly coupled cell population found in both control and cold stressed rats and a highly coupled cell population only found in stressed animals.

Biophysical properties of the electrical coupling were next investigated by recording macroscopic junctional currents $\left(I_{\mathrm{j}}\right)$ in chromaffin cell pairs voltage clamped at $-60 \mathrm{mV}$ (Fig. 2). Delivering voltage steps with command pulses of both polarities triggered $I_{\mathrm{j}}$ in the unstepped cell that displayed a variable degree of attenuation (Fig. $2 \mathrm{~A}$ ). Consistent with the presence of weakly and highly coupled chromaffin cell pairs in stressed rats, the coupling ratio exhibited a bimodal distribution over the range $0.02-0.97$ (Fig. $2 \mathrm{~B}$ ). When plotted as a function of the transjunctional potential, the $I-V$ curve of $I_{\mathrm{j}}$ displayed a linear relationship within the membrane potential range of -60 to $+120 \mathrm{mV}$. The curve used to fit the data were derived from a linear regression, giving a mean macroscopic junctional conductance $G_{j}$ for weak coupling of $169 \pm 10$ and $248 \pm 32 \mathrm{pS}$ for control and stressed rats, respectively, and for robust coupling of $5.79 \pm$ $0.56 \mathrm{nS}$ for stressed rats (Fig. 2C). In all cell pairs exhibiting a coupling ratio value above 0.66 (i.e., as found in $\sim 50 \%$ of coupled pairs in stressed rats), the evoked action potential was transmitted to the unstepped cell.

With the aim to examine whether electrical coupling was mediated by gap junctions, chromaffin cell pairs from control, cold exposed, and rescued rats were recorded in the presence of the pharmacological decoupling agent carbenoxolone (Ishimatsu and Williams, 1996). $I_{\mathrm{j}}$ amplitude was continuously recorded before and during a 15 min carbenoxolone bath application (Fig. 3Aa). As expected for a current flowing through gap junction channels, $I_{j}$ amplitude rapidly decreased after carbenoxolone application, whereas it remained unchanged in control saline. The carbenoxolone-induced full decoupling effect was observed within $15 \mathrm{~min}$. The effect of carbenoxolone was partly reversible ( $\sim 50 \%$ within $10-12$ min after washout; $n=4-8$ ) (Fig. 3Ab). Consistent with a gap junction-mediated process, pretreatment with $100 \mu \mathrm{M}$ carbenoxolone (15 min before recording) prevented the appearance of electrical coupling in pairs from control, cold exposed, and rescued rats (Fig. 3B).

Together, these results clearly show an upregulation of gap junction-mediated chromaffin cell communication in the adrenal medulla of cold stressed rats, resulting in the appearance of a robust electrical coupling.
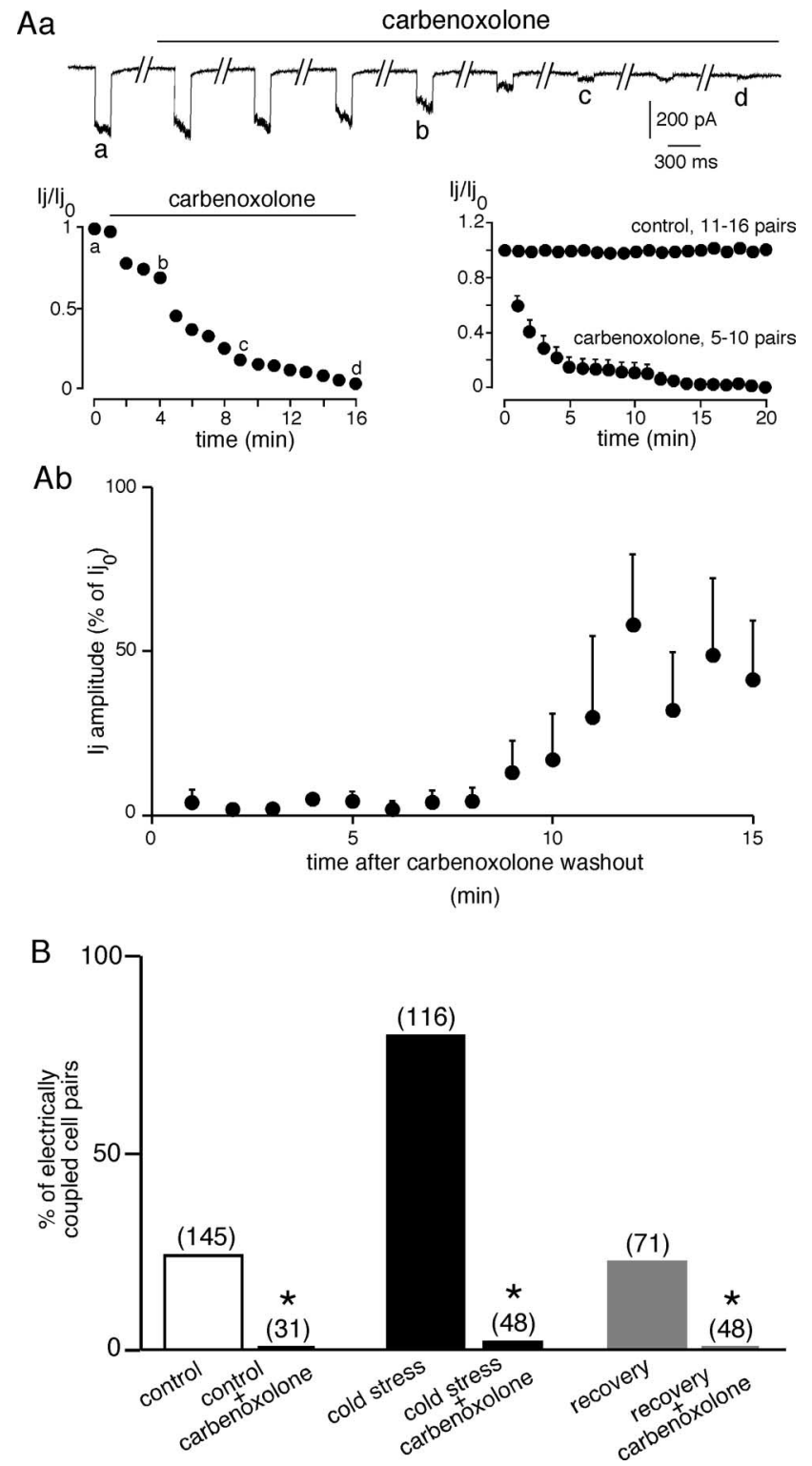

Figure 3. Reversible inhibition of electrical coupling by the gap-junctional blocker carbenoxolone. $\boldsymbol{A}$, Time course of the blocking effect of carbenoxolone on $\boldsymbol{I}_{\mathrm{j}}$. $\boldsymbol{A a}, \boldsymbol{I}_{\mathrm{j}}$ amplitude was continuously monitored in a chromaffin cell pair (stressed rat) voltage clamped at $-60 \mathrm{mV}$ before and during bath application of carbenoxolone (10-15 min). A voltage step ( $+40 \mathrm{mV}$, $150 \mathrm{~ms}$ ) was elicited every minute. Carbenoxolone gradually decreased $/ \mathrm{j}$ amplitude, leading to a complete blockade within a few minutes. Note the constant $I_{\mathrm{j}}$ amplitude during $20 \mathrm{~min}$ in control saline. $\boldsymbol{A} \boldsymbol{b}$, Partial recovery of $\boldsymbol{I}_{\mathrm{j}}$ amplitude after carbenoxolone washout. $\boldsymbol{B}$, Fifteenminute incubation with saline-containing carbenoxolone $(100 \mu \mathrm{m})$ dramatically reduced the percentage of electrically coupled chromaffin cells in control, stressed, and rescued rats. ${ }^{*} p<$ 0.01 , compared with values in the absence of carbenoxolone. The number of recorded cell pairs is indicated in parentheses.

\section{Upregulation of connexin 36 and connexin 43 protein expression levels in cold stressed rats}

We next conducted a series of experiments to characterize the mechanisms underlying the enhancement of junctional coupling in stressed rats. Gap junction function can be regulated at the transcriptional, translational, and posttranslational level (Oyamada et al., 2005). To determine whether connexin protein expression was modified in response to cold stress, immunofluorescent stainings using antibodies raised against $\mathrm{Cx} 36$ and $\mathrm{Cx} 43$ were performed on adrenal gland cryosections (Fig. 4). A typical 


\section{A $\times \times 36$ control}
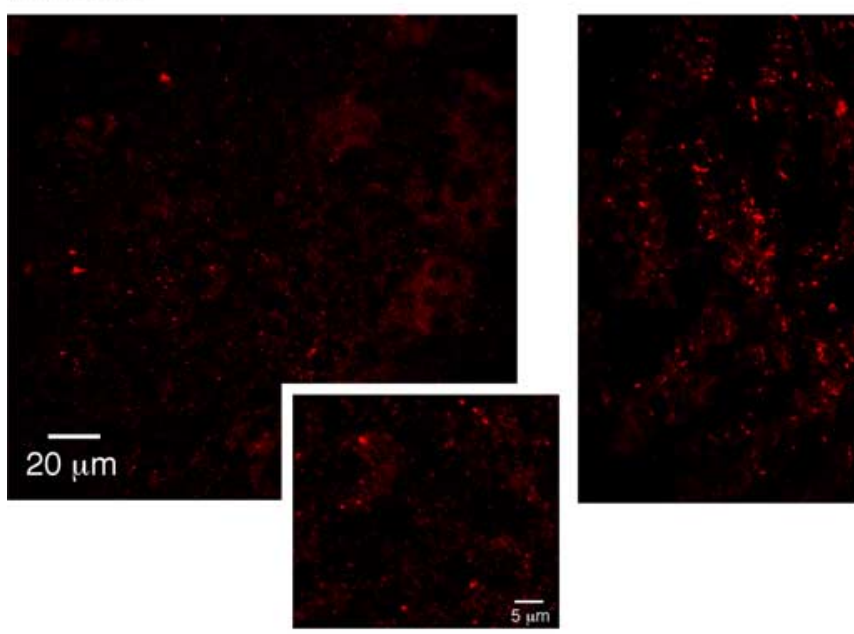

$\overline{5 \mu m}$

\section{B Cx43}
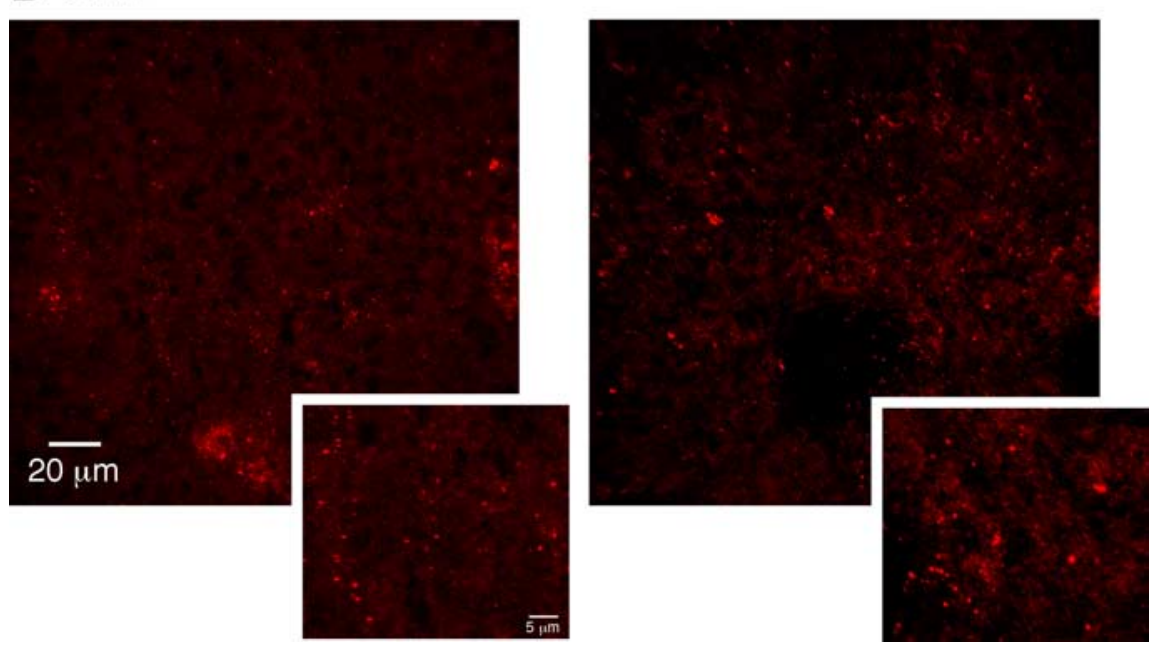

Figure 4. Immunofluorescent labeling of $C \times 36$ and $C \times 43$ in the adrenal medulla. $\boldsymbol{A}, \boldsymbol{B}$, Regular punctate appearance of $C \times 36(\boldsymbol{A})$ and $\mathrm{Cx} 43(\boldsymbol{B})$ staining. For both connexins, the labeling was denser in stressed rats compared with control. Insets, Higher magnification. In particular, note the presence of large fluorescent areas for (x36 immunoreactivity (arrowheads).

and eight cold exposed rats. Expression of connexin mRNA was normalized to the geometric mean of the expression levels of Hprt, GAPDH, and Gus mRNA. The Cx36 mRNA relative expression level was 2.5 fold higher in stressed rats $(21.0 \pm 6.5 \mathrm{vs}$ $8.4 \pm 1.5$ in stressed and control rats, respectively; $p<0.05)$. No change was observed for Cx43 transcripts (relative expression: stressed rats, $14746 \pm 1193$ vs control rats, $14517 \pm 1565 ; p>0.05$ ), thus indicating that other mechanisms were involved. We therefore addressed the involvement of posttranslational changes such as stability of gap-junctional plaques. Anchored gap junctions at the plasma membrane are reported to bind to scaffolding proteins, such as ZO-1. This PDZ (postsynaptic density-95/Discs large/ $\mathrm{ZO}-1)$ domain-containing protein has been shown to interact with various connexins including Cx36 and Cx43 (Giepmans and Moolenaar, 1998; Li et al., 2004). Although ZO-1 function at the gap junction still remains elusive, it has been suggested that ZO-1 may contribute to the assembly and/or stability of gap junctions (Laing et al., 2005; Singh et al., 2005). As illustrated in Figure 6, ZO-1 expression is upregulated in cold stressed rats, and densitometric analysis of immunoblots indicates that the ZO-1 expression level is twofold higher in stressed rats $(p<0.01$, compared with unstressed rats).

\section{Physiological relevance of increased gap-junctional coupling} Increased spontaneous $\left[\mathrm{Ca}^{2+}\right]_{i}$ coactivity between chromaffin cells in cold stressed rats Because gap junction-mediated cell-cell communication can support synchronous activity between endocrine/neuroendo-

punctate fluorescence was observed for both connexins in control and stressed rats. However, the labeling of both Cx36 and Cx43 appeared more abundant in cold stressed compared with unstressed animals. In addition, Cx36-containing gap junction plaques seemed larger in size (Fig. $4 A$, insets). To go further, membrane content of $\mathrm{Cx} 36$ and $\mathrm{Cx} 43$ was measured by Western blot. Consistent with our immunofluorescent data, $\mathrm{Cx} 36$ and Cx43 protein levels were upregulated in stressed rats (Fig. 5A). To analyze the data, the levels of $\mathrm{Cx} 36$ and $\mathrm{Cx} 43$ were normalized to those of actin used as a loading control. Quantitative analysis summarized in Figure $5 B$ indicates a threefold and twofold increase for $\mathrm{Cx} 36$ and $\mathrm{Cx} 43$, respectively $(p<0.01)$.

Several mechanisms, which are not mutually exclusive, could account for the cold stress-induced increase in connexin levels. It may be a consequence of increased synthesis, increased stability at the plasma membrane, and/or decreased degradation. As a first step toward the characterization of the mechanisms involved in increased connexin expression in cold exposed rats, we examined by real-time PCR whether the expression level of Cx36 and Cx43 transcripts was modified (data not shown). Total RNA was extracted from macrodissected adrenal medulla from eight control crine cells (Guérineau et al., 1998; Martin et al., 2001), we imaged spontaneous changes in cytosolic $\mathrm{Ca}^{2+}$ concentration $\left(\left[\mathrm{Ca}^{2+}\right]_{\mathrm{i}}\right)$ in chromaffin cell clusters using real-time confocal microscopy. Coactive cell clusters were found both in slices from control and cold stressed rats, but in the latter, the occurrence was significantly higher $(72.5 \%, n=69$ recorded cell fields vs $43.9 \%, n=41$ in control rats; $p<0.01$ ) (Fig. 7). However, the extent of spontaneous $\left[\mathrm{Ca}^{2+}\right]_{\mathrm{i}}$ coactivity did not differ between control and stressed rats and appeared to be restricted to a limited number of cells (two to three on the same optical plane). To determine whether gap-junctional coupling was involved in the coactivity process, spontaneous $\left[\mathrm{Ca}^{2+}\right]_{\mathrm{i}}$ changes in stressed rats were recorded in carbenoxolone-containing saline (100 $\mu \mathrm{M}, 15 \mathrm{~min}$ before testing). As shown in the histogram, coactive cell clusters occurred less frequently than in control conditions $(p<0.01)$.

Extended nicotine-induced synchronous multicellular $\left[\mathrm{Ca}^{2+}\right]_{i}$ increases in cold stressed rats

As reported previously (Martin et al., 2001), the gap junctiondelineated route between adrenal chromaffin cells allows synchronous multicellular $\left[\mathrm{Ca}^{2+}\right]_{\mathrm{i}}$ responses after nicotinic stimu- 

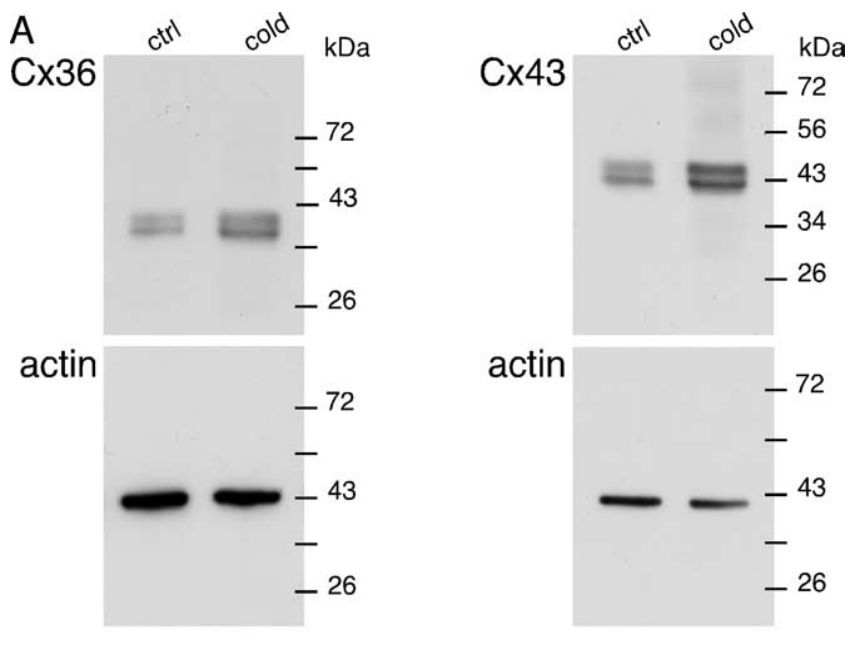

B

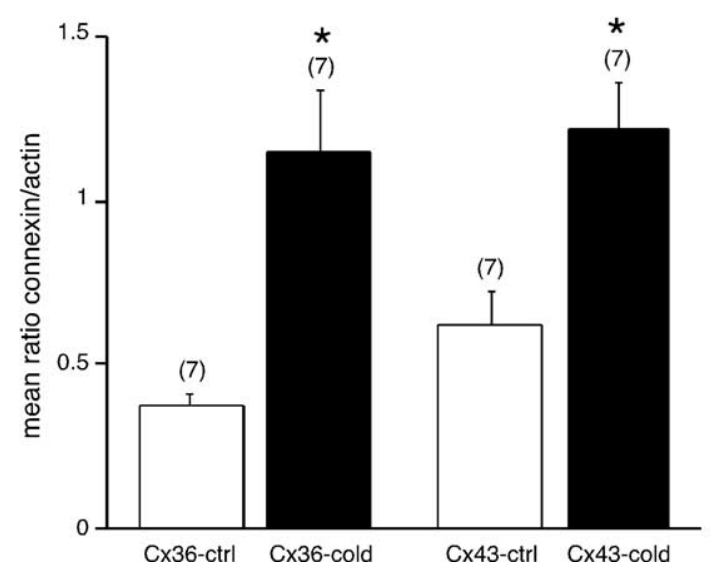

Figure 5. Connexin 36 and connexin 43 protein expression levels are upregulated in cold stressed rats. Connexin expression levels were measured by Western blot. $\boldsymbol{A}$, Representative immunoblots showing specific detection of $\mathrm{C} \times 36$ and $\mathrm{C} \times 3$ in the adrenal medulla of control and stressed rats. Actin was used as internal loading control. $\boldsymbol{B}$, Histogram summarizing the densitometric analysis of immunoblots (normalized by actin) from seven control and seven stressed rats. Quantitative analysis shows that $\mathrm{Cx} 36$ and $\mathrm{Cx} 43$ expression was significantly increased in stressed rats (3- and 2-fold increase, respectively). ${ }^{*} p<0.01$, compared with unstressed rats. ctrl, Control. The number of rats used for each condition is indicated in parentheses.

lation. What are the consequences of an upregulated electrical coupling on nicotine-induced synchronous $\mathrm{Ca}^{2+}$ signaling in chromaffin cell clusters in cold stressed rats? To address this issue, nicotine-evoked changes in $\left[\mathrm{Ca}^{2+}\right]_{\mathrm{i}}$ in chromaffin cells were imaged in both control and cold exposed rats. Only cell fields in which the iontophoretic application of nicotine triggered a $\mathrm{Ca}^{2+}$ response in the stimulated cell were taken into consideration. In control slices, simultaneous transient $\left[\mathrm{Ca}^{2+}\right]_{\mathrm{i}}$ rises were observed in $63 \%$ of stimulated cell clusters $(n=27)$, and the extent of coactivity was mainly restricted to one to two adjoining cells (Fig. $8 A$, left, $B$, open bars). In contrast, in $81.8 \%$ of tested cell clusters $(n=55)$ in stressed rats, a large number of chromaffin cells (up to 11 in the same optical focus) displayed simultaneous $\left[\mathrm{Ca}^{2+}\right]_{\mathrm{i}}$ coactivity in response to nicotine iontophoresis (Fig. $8 A$, right, $B$, filled bars). The propagated signal between chromaffin cells reliably persisted after repetitive applications of nicotine, indicating that the intercellular mechanism underlying the propagation did not desensitize during the recording time (data not shown). To determine whether gap junctions were involved in the $\left[\mathrm{Ca}^{2+}\right]_{\mathrm{i}}$ coactivity process, similar experiments were performed in stressed rats in the presence of carbenoxolone. Bath-applied car-

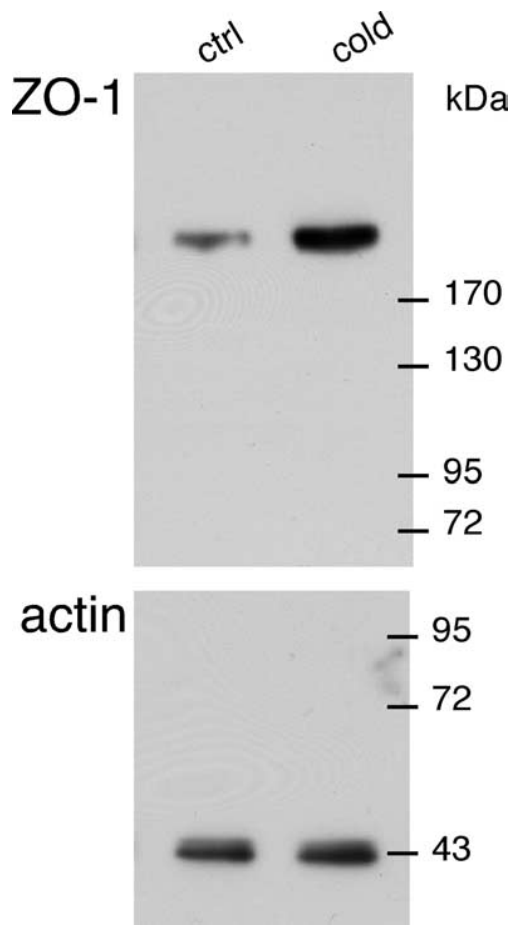

Figure 6. Increased 20-1 expression level in adrenal medulla of cold stressed rats. An immunoblot illustrating the upregulation of the Z0-1 expression level in stressed rats $(n=6)$ compared with unstressed rats $(n=6)$ is shown. ctrl, Control.

benoxolone (100 $\mu \mathrm{M}, 15$ min before testing) significantly reduced the occurrence of spontaneous coactivation between adjacent chromaffin cells $(10.6 \%, n=47$ vs $72.5 \%, n=69$ in the presence and in the absence of carbenoxolone, respectively; $p<0.01$; data not shown). Additionally, the iontophoretic nicotine application $(10 \mathrm{~ms})$ triggered simultaneous $\left[\mathrm{Ca}^{2+}\right]_{\mathrm{i}}$ coactivity only in $16.7 \%$ of stimulated clusters $(n=24)$ compared with $81.8 \%$ without carbenoxolone $(p<0.01)$ (Fig. $8 C$ ). As reported previously (Martin et al., 2001), carbenoxolone modified neither the percentage of spontaneously active cells nor the amplitude and duration of the nicotine-activated $\mathrm{Ca}^{2+}$ response (data not shown). Another set of data also confirmed the involvement of gap junctions. First, the calculation of the speed of nicotine-induced signal propagation, based on a $20 \mu \mathrm{m}$ distance between adjacent chromaffin cell centers in rat (Martin et al., 2001), is consistent with a gap-junctional-mediated pathway $(716 \pm 52 \mu \mathrm{m} / \mathrm{s}, n=$ 124 vs $435 \pm 49 \mu \mathrm{m} / \mathrm{s}, n=31 ; p<0.01)$. Second, as control experiments of iontophoretic application of nicotine, we showed that current polarity inversion $(n=18)$ or application of nicotine-free saline $(n=11)$ never induced $\left[\mathrm{Ca}^{2+}\right]_{\mathrm{i}}$ changes in either stimulated or adjacent cells. Moreover, extracellular diffusion of nicotine could reasonably be ruled out because (1) a $\left[\mathrm{Ca}^{2+}\right]_{\mathrm{i}}$ increase was not observed in all cells belonging to the same cluster, whereas all these cells were sensitive to pressure ejection of nicotine and (2) in some experiments, only the stimulated cell exhibited a $\left[\mathrm{Ca}^{2+}\right]_{\mathrm{i}}$ rise.

These results point out the functional role played by gapjunctional communication in the expression of synchronized $\mathrm{Ca}^{2+}$ signals between chromaffin cells, in particular in cold stressed rats.

\section{Discussion}

This study reports a functional remodeling of gap junctionmediated intercellular communication in the adult rat adrenal 

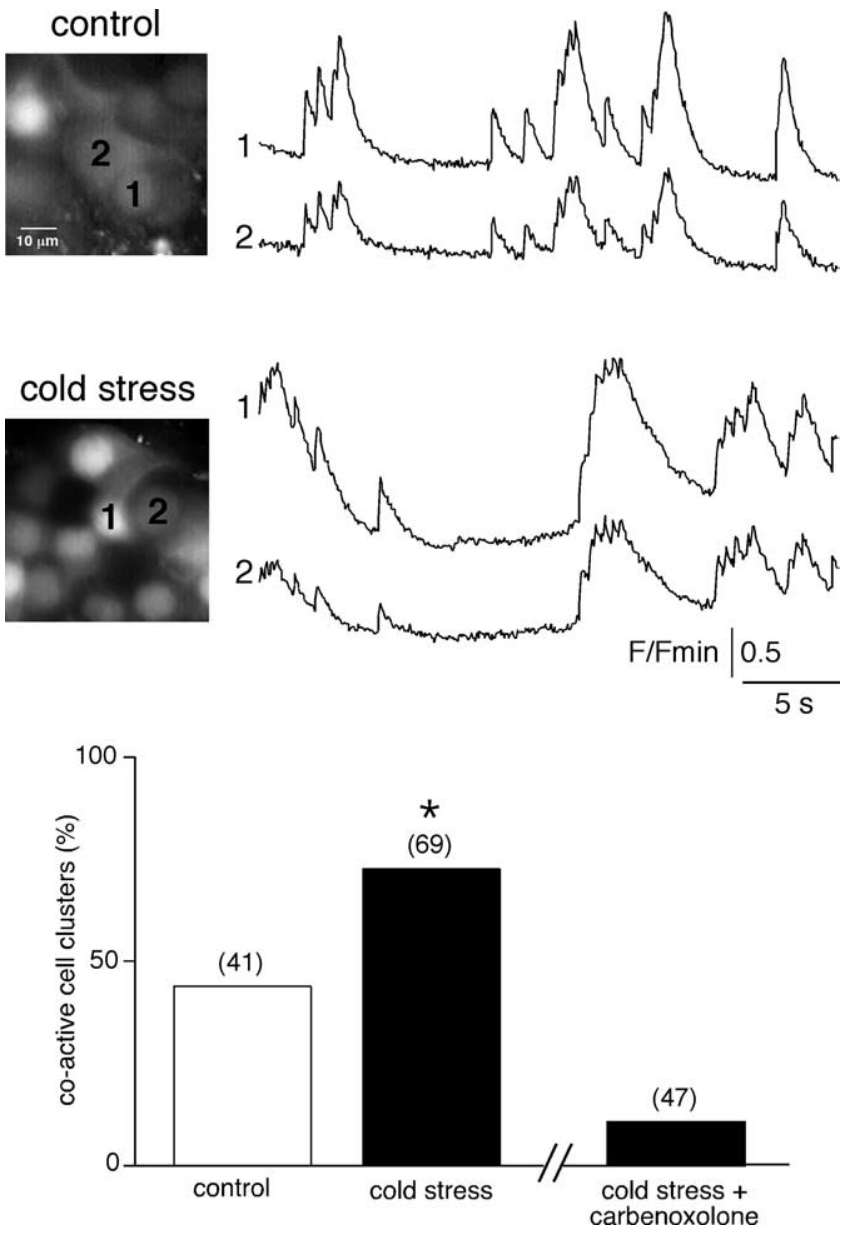

Figure 7. Spontaneous $\left[\mathrm{Ca}^{2+}\right]_{\mathrm{i}}$ coactivity in chromaffin cell doublets. Real-time spontaneous $\left[\mathrm{Ca}^{2+}\right]_{\mathrm{i}}$ changes were imaged in Oregon Green 488 BAPTA-1-loaded adrenal slices. Chromaffin cells from both control and stressed rats exhibited synchronized coactivities that did not exceed cell doublets or triplets. The histogram shows that spontaneously coactive cell clusters occurred more frequently in stressed rats. Note that the percentage of spontaneous coactive cell clusters is dramatically reduced in carbenoxolone-containing saline (100 $\mu \mathrm{m}, 15 \mathrm{~min}$ before testing). The number of recorded cell fields is indicated in parentheses. ${ }^{*} p<0.01$ compared with unstressed rats.

medulla in response to cold stress. The increased electrical coupling between chromaffin cells likely contributes to improve the stimulus-secretion coupling efficiency and may therefore represent one of the endogenous mechanisms by which the medulla ensures appropriate sustained catecholamine secretion in response to stressful conditions.

\section{Appearance of a robust electrical coupling in cold stressed rats: a functional support for coordinating multicellular $\left[\mathrm{Ca}^{2+}\right]_{\mathrm{i}}$ rises between chromaffin cells}

We show that a persistent cold exposure induces a robust electrical coupling between chromaffin cells. Two populations of electrically coupled cells can be distinguished in stressed rats, based on junctional conductance values. Although a weak coupling allows small depolarizations to propagate after action potential firing, a robust coupling triggers action potentials in the coupled cells. The contribution of Cx36- and/or Cx43-built channels to weak versus robust coupling is unknown, but because connexin channels exhibit different voltage sensitivities (Gonzalez et al., 2007), their roles in propagating electrical signals between adjacent cells likely differ. The weak voltage dependence of Cx36 channels suggests that electrical coupling may not be disrupted during secretagogue-mediated action potential discharges. In contrast, $\mathrm{Cx} 43$ channels that are highly voltage sensitive may predominantly be regulated during firing. Cold stress induces an increased expression of both $\mathrm{Cx} 36$ and $\mathrm{Cx} 43$ proteins, but by different mechanisms because only Cx36 mRNA is upregulated. The fact that some cells coexpress both mRNAs (Martin et al., 2001) supports the hypothesis that chromaffin cells might express both connexins and regulate their synthesis differently. Alternatively, two cell populations may exist, expressing either Cx36 or Cx43 under different conditions. A possibility would then be that stress leads to an upregulation of one population. Only a double electron microscopy study would reliably address this issue.

We show that occurrence of the highly coupled cell population in cold stressed rats correlates with long-distance activation of simultaneous $\left[\mathrm{Ca}^{2+}\right]_{\mathrm{i}}$ increases in coupled cells. The high speed of $\left[\mathrm{Ca}^{2+}\right]_{\mathrm{i}}$ coactivation between chromaffin cells in response to nicotinic stimulation of a single cell likely results from gap junction-mediated propagation of a depolarizing wave. Although we cannot definitively rule out the involvement of other communication modes (such as paracrine action of factors coreleased with catecholamines), gap junctions likely represent the anatomical correlate of the functional coupling observed here. Several observations support this proposal: (1) propagation of electrical events between two adjacent cells; (2) junctional current recorded in cell pairs; and (3) carbenoxolone-induced reduction in junctional currents and simultaneous $\left[\mathrm{Ca}^{2+}\right]_{\mathrm{i}}$ changes after nicotinic stimulation.

As reported for pancreatic $\beta$-cells in which gap-junctional coupling provides the basis for coordinating agonist-induced $\left[\mathrm{Ca}^{2+}\right]_{\mathrm{i}}$ oscillations (Calabrese et al., 2003), it is likely that the extended electrical activity propagation through robustly coupled chromaffin cells supports multicellular $\left[\mathrm{Ca}^{2+}\right]_{\mathrm{i}}$ coactivities within cell clusters. Moreover, our data strongly support the postulate that propagation of action potentials between chromaffin cells via electrotonic coupling may amplify the secretory signal to ensure massive catecholamine release in the intact gland (Ceña et al., 1983). Because propagation of electrical signals and associated $\left[\mathrm{Ca}^{2+}\right]_{\mathrm{i}}$ transients is more efficient between highly coupled cells than between weakly coupled cells, we propose that the robust coupling has a strong influence on the stimulus-secretion coupling and may account for the enhancement of plasma catecholamine levels found in cold exposed rats (Kvetnansky et al., 1971).

\section{Long-term persistence of changes in gap \\ junction-mediated communication}

In addition to short-term changes, gap-junctional coupling also undergoes long-term plasticity associated with functional changes that can persist for weeks (Chang et al., 2000; Martin et al., 2003). Modulation of connexin expression at the transcriptional level (Oyamada et al., 2005), connexin assembly into functional channels, modification of existing gap junction plaques (Chang et al., 2000), and/or steps affecting connexin number or trafficking (Martin et al., 2003) are possible targets involved in persistent changes of gap-junctional communication.

What cellular mechanisms could account for the sustained change in gap-junctional coupling strength observed in cold stressed rats? Our data indicate that both transcriptional and posttranslational mechanisms are involved, depending on the connexin. The enhancement of cell coupling in stressed rats parallels an increase in number of Cx36- and Cx43-built gap junctions, as found in pancreatic $\beta$-cells in response to a stimulation 

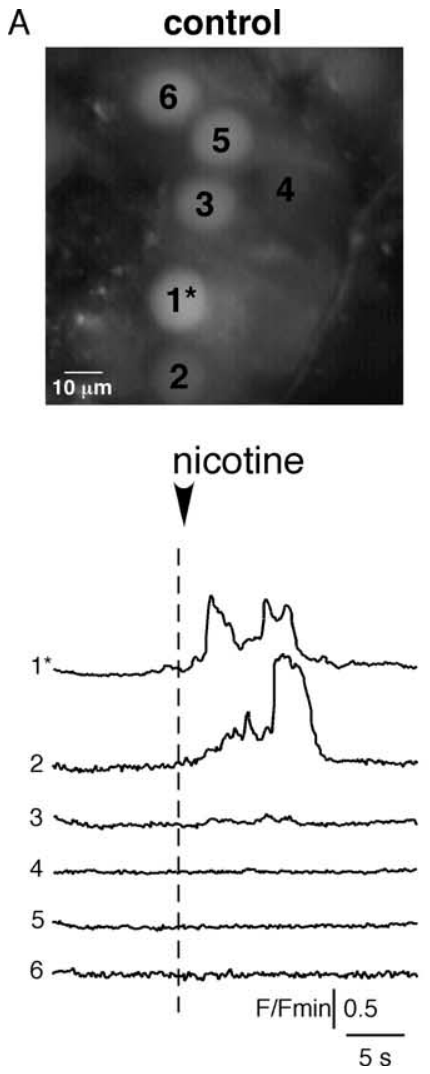
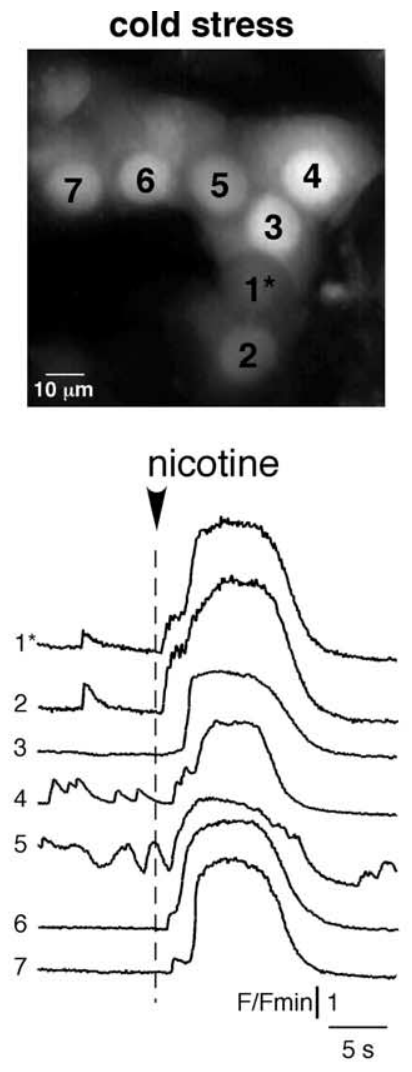
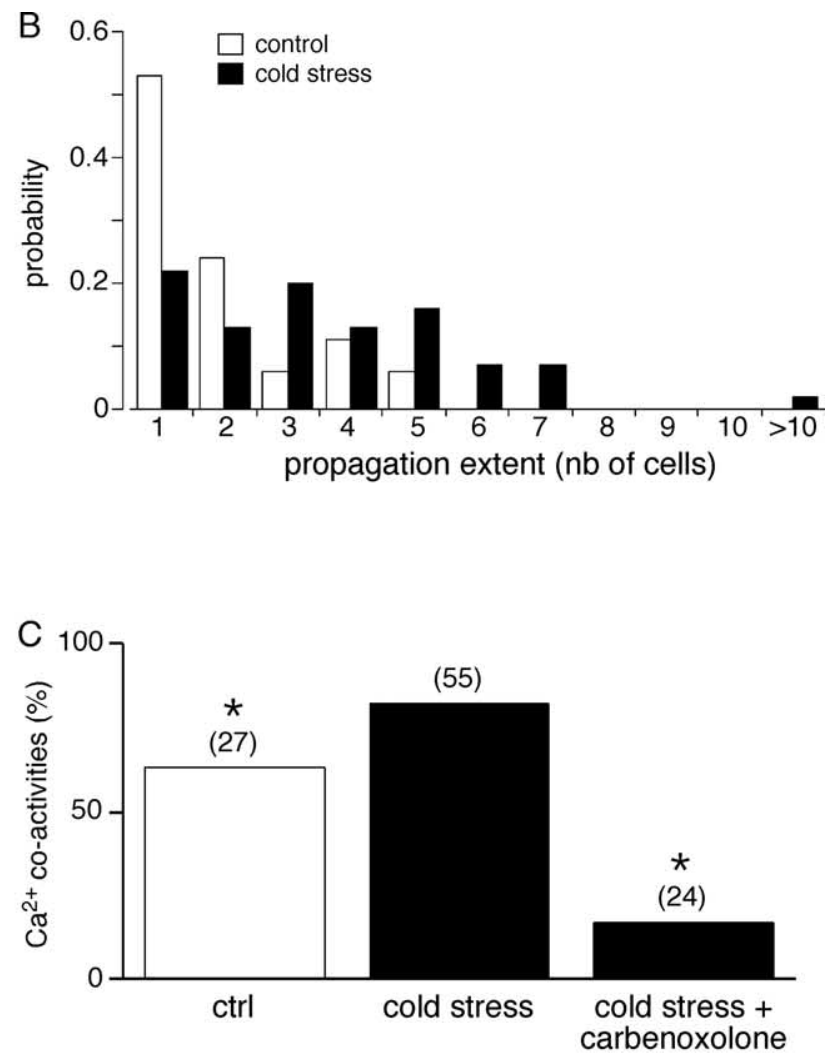

Figure 8. Extended nicotine-induced simultaneous $\left[\mathrm{Ca}^{2+}\right]_{i}$ increases between chromaffin cells in cold stressed rats. $\boldsymbol{A}$, Nicotine $(200 \mathrm{~mm}, 10 \mathrm{~ms})$ was iontophoretically applied on cell $1^{*}$ through a sharp microelectrode (the onset of the nicotinic stimulation is indicated by an arrow), and $\left[\mathrm{Ca}^{2+}\right]_{i}$ changes were imaged using real-time confocal microscopy. In a control rat (left), the $\left[\mathrm{Ca}^{2+}\right]_{i}$ increase originating in the stimulated cell was simultaneously detected in one adjacent cell, whereas in a stressed rat, simultaneous [Ca $\left.{ }^{2+}\right]_{i}$ increases were recorded in up to six adjacent cells (right). $\boldsymbol{B}$, Extented coactivity of nicotine-triggered $\left[\mathrm{Ca}^{2+}\right]_{i}$ rises in stressed rats compared with untressed rats. $\boldsymbol{C}$, Significant reduction in nicotine-induced $\left[\mathrm{Ca}^{2+}\right]_{i}$ coactivities in nonstimulated cells in the presence of the gap junction blocker carbenoxolone (100 $\mu \mathrm{m}, 15 \mathrm{~min}$ bath application before recording). The number of recorded cell fields is indicated in parentheses. ${ }^{*} p<0.01$ compared with cold stressed rats.

of insulin release (Collares-Buzato et al., 2001). A means to control junctional communication is the modulation of connexin life cycle and stability at the plasma membrane. This occurs through interaction with a variety of scaffolding proteins (Hervé et al., 2007) that can act by preventing interaction with degradation machinery or by forming complexes between connexins and the cytoskeleton (Butkevich et al., 2004). Our results showing that the ZO-1 expression level, a scaffolding protein interacting with both Cx36 and Cx43 (Giepmans and Moolenaar, 1998; Li et al., 2004), is upregulated in stressed rats are in agreement with our proposal that $\mathrm{Cx} 36$ and/or $\mathrm{Cx} 43$ may be stabilized at the plasma membrane, leading to a slowdown of connexin turnover. Consistent with this hypothesis is the demonstration that (1) Cx43 turns over at a more rapid rate when it no longer interacts with $\mathrm{ZO}-1$ (Toyofuku et al., 2000), (2) disruption of the association between $\mathrm{Cx} 43$ and ZO-1 reduces junctional communication, and (3) transfer of $\mathrm{Cx} 43$ to the plasma membrane is affected by changes in the abundance of ZO-1 (Laing et al., 2005). Alternatively, interaction between ZO-1 and Cx36/Cx43 may modify their trafficking and/or facilite their interactions with other proteins. As shown by qPCR experiments and reported for genes encoding catecholamine-synthesizing enzymes and related transcription factors (Baruchin et al., 1990; Sabban and Kvetnansky, 2001; Sabban et al., 2006), mechanisms taking place at the transcriptional level can also be involved. We show that in cold stressed rats, the Cx36 protein expression level faithfully parallels the Cx36 mRNA expression level, as opposed to $\mathrm{Cx} 43$, for which the mRNA ex- pression level remains unchanged. Whether or not other connexin-related genes are affected remains unknown.

In the adrenal medulla, the degree of junctional coupling between chromaffin cells is also under a tonic control exerted by cholinergic synaptic inputs (Martin et al., 2003). Because the sympatho-adrenal system is activated during cold stress, one could propose that synaptically released factors might acutely and chronically modulate intercellular coupling (Hatton, 1998). To address this issue, additional experiments conducted in denervated adrenals are required. Activation of the hypothalamopituitary-corticoadrenal axis is also an important component of the stress response. Because cortical and medullary tissues interact with each other (Einer-Jensen and Carter, 1995; Bornstein et al., 1997), gap-junctional coupling between chromaffin cells could be regulated by factors released from the cortex such as adrenocorticotropin, reported to increase Cx43-mediated communication (Murray et al., 2003). Although we cannot definitively rule out the involvement of cortical factors in cold stressinduced increased junctional coupling, it is noteworthy that a cold exposure induces only a weak activation of the hypothalamo-pituitary-adrenocortical axis (Pacak et al., 1995).

Physiological relevance of upregulated connexin expression in stressed rats: increased stimulation-secretion coupling efficiency

The upregulation of gap-junctional coupling in cold stressed rats results in an increase in both spontaneous and nicotine-evoked 
simultaneous $\left[\mathrm{Ca}^{2+}\right]_{\mathrm{i}}$ rises between chromaffin cells. Because $\left[\mathrm{Ca}^{2+}\right]_{\mathrm{i}}$ rise is a prerequisite for exocytosis and because cell-cell communication contributes to catecholamine release (Martin et al., 2001), we propose that the increased gap-junctional coupling described here in cold stressed rats is physiologically relevant in terms of catecholamine secretion. Additional experiments are required to definitively assess the causal link between upregulated gap-junctional coupling and increased secretory function. With regard to neuroendocrine secretion, an increase in number and expression of gap junctions has also been reported in $\beta$-cells in response to stimulation of insulin release (Collares-Buzato et al., 2001). In addition, during maturation of neonatal pancreatic islets, the gain of capacity of the islet to secrete insulin is associated with an increased Cx36 expression (Leite et al., 2005). Moreover, it is noteworthy that an increased gap-junctional communication between chromaffin cells has been also found in rats exposed to a restraint stress (C. Colomer and N. C. Guérineau, unpublished observations). Our data demonstrate that, among adaptative responses to stress, an increase in catecholamine secretion is associated with an upregulation of gap-junctional communication between chromaffin cells. Gap junction expression in numerous tissues prompts us to hypothesize that this unanticipated role of gap-junctional coupling might be extended to other stressresponsive tissues and, more generally, that an upregulation of gap-junctional communication between neuroendocrine/endocrine cells might be a general mechanism whereby secretory tissues dynamically adapt to increased hormonal demands.

Another interesting outcome of our data deals with the influence of previous experience with the homotypic/heterotypic stressor on the reactivity of adrenomedullary system to subsequent stress. As reported previously (Ma and Morilak, 2005; Sabban and Serova, 2007), cold stress exposure sensitizes catecholaminergic systems of the adrenal medulla and the locus ceruleus. An upregulated gap-junctional communication between chromaffin cells might be one endogenous mechanism whereby the adrenomedullary system is sensitized. Such functional sensitization could be an important component for stress adaptation and may also contribute to dysregulation of the stress response.

\section{References}

Baruchin A, Weisberg EP, Miner LL, Ennis D, Nisenbaum LK, Naylor E, Stricker EM, Zigmond MJ, Kaplan BB (1990) Effect of cold exposure on rat adrenal tyrosine hydroxylase: an analysis of RNA, protein, enzyme activity and co-factor levels. J Neurochem 54:1769-1775.

Bornstein SR, Ehrhart-Bornstein M, Scherbaum WA (1997) Morphological and functional studies of the paracrine interaction between cortex and medulla in the adrenal gland. Microsc Res Tech 36:520-533.

Bradford MM (1976) A rapid and sensitive method for the quantitation of microgram quantities of protein utilizing the principle of protein-dye binding. Anal Biochem 72:248-254.

Butkevich E, Hulsmann S, Wenzel D, Shirao T, Duden R, Majoul I (2004) Drebrin is a novel connexin- 43 binding partner that links gap junctions to the submembrane cytoskeleton. Curr Biol 14:650-658.

Calabrese A, Zheng M, Serre-Beinier V, Caton D, Mas C, Satin LS, Meda P (2003) Connexin 36 controls synchronization of $\mathrm{Ca}^{2+}$ oscillations and insulin secretion in MIN6 cells. Diabetes 52:417-424.

Caton D, Calabrese A, Mas C, Serre-Beinier V, Wonkam A, Meda P (2002) Beta-cell crosstalk: a further dimension in the stimulus-secretion coupling of glucose-induced insulin release. Diabetes Metab 28:3S45-3S53.

Ceña V, Nicolas GP, Sanchez-Garcia P, Kirpekar SM, Garcia AG (1983) Pharmacological dissection of receptor-associated and voltage-sensitive ionic channels involved in catecholamine release. Neuroscience 10:1455-1462.

Chang Q, Pereda A, Pinter MJ, Balice-GordonRJ (2000) Nerve injury induces gap junctional coupling among axotomized adult motor neurons. J Neurosci 20:674-684.
Charmandari E, Tsigos C, Chrousos G (2005) Endocrinology of the stress response. Annu Rev Physiol 67:259-284.

Collares-Buzato CB, Leite AR, Boschero AC (2001) Modulation of gap and adherent junctional proteins in cultured neonatal pancreatic islets. Pancreas 23:177-185.

Douglas WW (1968) Stimulus-secretion coupling: the concept and clues from chromaffin and other cells. Br J Pharmacol 34:451-474.

Einer-Jensen N, Carter AM (1995) Local transfer of hormones between blood vessels within the adrenal gland may explain the functional interaction between the adrenal cortex and medulla. Med Hypotheses 44:471-474.

Giepmans BN, Moolenaar WH (1998) The gap junction protein connexin 43 interacts with the second PDZ domain of the zona occludens- 1 protein. Curr Biol 8:931-934.

Goldstein DS, Kopin IJ (2007) Evolution of concepts of stress. Stress 10:109-120.

Gonzalez D, Gomez-Hernandez JM, Barrio LC (2007) Molecular basis of voltage dependence of connexin channels: an integrative appraisal. Prog Biophys Mol Biol 94:66-106.

Grouzmann E, Werffeli-George P, Fathi M, Burnier M, Waeber B, Waeber G (1994) Angiotensin-II mediates norepinephrine and neuropeptide-Y secretion in a human pheochromocytoma. J Clin Endocrinol Metab 79:1852-1856.

Guérineau NC, Bonnefont X, Stoeckel L, Mollard P (1998) Synchronized spontaneous $\mathrm{Ca}^{2+}$ transients in acute anterior pituitary slices. J Biol Chem 273:10389-10395.

Hamill OP, Marty A, Neher E, Sakmann B, Sigworth FJ (1981) Improved patch-clamp techniques for high-resolution current recording from cells and cell-free membrane patches. Pflugers Arch 391:85-100.

Hatton GI (1997) Function-related plasticity in hypothalamus. Annu Rev Neurosci 20:375-397.

Hatton GI (1998) Synaptic modulation of neuronal coupling. Cell Biol Int 22:765-780.

Herman JP, Cullinan WE (1997) Neurocircuitry of stress: central control of the hypothalamo-pituitary-adrenocortical axis. Trends Neurosci 20:78-84.

Hervé JC, Bourmeyster N, Sarrouilhe D, Duffy H (2007) Gap junctional complexes: from partners to functions. Prog Biophys Mol Biol 94:29-64.

Ishimatsu M, Williams JT (1996) Synchronous activity in locus coeruleus results from dendritic interactions in pericoerulear regions. J Neurosci 16:5196-5204.

Kvetnansky R, Sabban EL (1993) Stress-induced changes in tyrosine hydroxylase and other catecholamine biosynthetic enzymes. In: Tyrosine hydroxylase: from discovery to cloning (Naoi M, Parvez SH, eds), pp 253-281. Utrecht, The Netherlands: VSP.

Kvetnansky R, Gewirtz GP, Weise VK, Kopin IJ (1971) Catecholaminesynthesizing enzymes in the rat adrenal gland during cold exposure. Am J Physiol 220:928-931.

Kvetnansky R, Pacak K, Sabban EL, Kopin IJ, Goldstein DS (1998) Stressor specificity of peripheral catecholaminergic activation. In: Advances in pharmacology (Goldstein DS, Eisenhofer G, McCarty R, eds), pp 556560. San Diego: Academic.

Laing JG, Chou BC, Steinberg TH (2005) ZO-1 alters the plasma membrane localization and function of $\mathrm{Cx} 43$ in osteoblastic cells. J Cell Sci 118:2167-2176.

Leite AR, Carvalho CP, Furtado AG, Barbosa HC, Boschero AC, CollaresBuzato CB (2005) Co-expression and regulation of connexins 36 and 43 in cultured neonatal rat pancreatic islets. Can J Physiol Pharmacol 83:142-151.

Li X, Olson C, Lu S, Nagy JI (2004) Association of connexin36 with zonula occludens- 1 in HeLa cells, betaTC-3 cells, pancreas, and adrenal gland. Histochem Cell Biol 122:485-498.

Ma S, Morilak DA (2005) Chronic intermittent cold stress sensitises the hypothalamic-pituitary-adrenal response to a novel acute stress by enhancing noradrenergic influence in the rat paraventricular nucleus. J Neuroendocrinol 17:761-769.

Martin AO, Mathieu M-N, Chevillard C, Guérineau NC (2001) Gap junctions mediate electrical signaling and ensuing cytosolic $\mathrm{Ca}^{2+}$ increases between chromaffin cells in adrenal slices: a role in catecholamine release. J Neurosci 21:5397-5405.

Martin AO, Mathieu M-N, Guérineau NC (2003) Evidence for long-lasting 
cholinergic control of gap junctional communication between adrenal chromaffin cells. J Neurosci 23:3669-3678.

Meda P (1996) The role of gap junction membrane channels in secretion and hormonal action. J Bioenerg Biomembr 28:369-377.

Michon L, Nlend Nlend R, Bavamian S, Bischoff L, Boucard N, Caille D, Cancela J, Charollais A, Charpantier E, Klee P, Peyrou M, Populaire C, Zulianello L, Meda P (2005) Involvement of gap junctional communication in secretion. Biochim Biophys Acta 1719:82-101.

Munari-Silem Y, Rousset B (1996) Gap junction-mediated cell-to-cell communication in endocrine glands-molecular and functional aspects: a review. Eur J Endocrinol 135:251-264.

Murray SA, Davis K, Gay V (2003) ACTH and adrenocortical gap junctions. Microsc Res Tech 61:240-246.

Neyton J, Trautmann A (1985) Single-channel currents of an intercellular junction. Nature 317:331-335.

Oyamada M, Oyamada Y, Takamatsu T (2005) Regulation of connexin expression. Biochim Biophys Acta 1719:6-23.

Pacak K, Palkovits M, Kvetnansky R, Yadid G, Kopin IJ, Goldstein DS (1995) Effects of various stressors on in vivo norepinephrine release in the hypothalamic paraventricular nucleus and on the pituitary-adrenocortical axis. Ann NY Acad Sci 771:115-130.

Sabban EL, Kvetnansky R (2001) Stress-triggered activation of gene expres- sion in catecholaminergic systems: dynamics of transcriptional events. Trends Neurosci 24:91-98.

Sabban EL, Serova LI (2007) Influence of prior experience with homotypic or heterotypic stressor on stress reactivity in catecholaminergic systems. Stress 10:137-143.

Sabban EL, Liu X, Serova L, Gueorguiev V, Kvetnansky R (2006) Stress triggered changes in gene expression in adrenal medulla: transcriptional responses to acute and chronic stress. Cell Mol Neurobiol 26:845-856.

Singh D, Solan JL, Taffet SM, Javier R, Lampe PD (2005) Connexin 43 interacts with zona occludens- 1 and -2 proteins in a cell cycle stage-specific manner. J Biol Chem 280:30416-30421.

Toyofuku T, Akamatsu Y, Zhang H, Kuzuya T, Tada M, Hori M (2000) $\mathrm{c}$-Src regulates the interaction between connexin- 43 and $\mathrm{ZO}-1$ in cardiac myocytes. J Biol Chem 276:1780-1788.

Vandesompele J, De Preter K, Pattyn F, Poppe B, Van Roy N, De Paepe A, Speleman F (2002) Accurate normalization of real-time quantitative RT-PCR data by geometric averaging of multiple internal control genes. Genome Biol 3:RESEARCH0034.

Wakade AR (1981) Studies on secretion of catecholamines evoked by acetylcholine or transmural stimulation of the rat adrenal gland. J Physiol 313:463-480. 